\title{
Nalaz citrinina u kukuruzu s hrvatskih obiteljskih gospodarstava tijekom petogodišnjeg razdoblja
}

\author{
J. Pleadin, N. Kudumija, T. Lešić, J. Frece, I. Kmetič, L. Dergestin Bačun i \\ K. Markov*
}

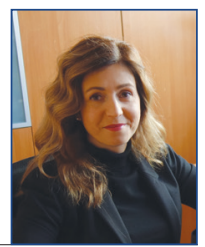

\section{Sažetak}

Mikotoksini učestalo kontaminiraju i hranu ljudi i hranu za životinje, ponajprije žitarice i proizvode na bazi žitarica. Citrinin je mikotoksin kojeg sintetiziraju pojedine plijesni iz roda Penicillium, Aspergillus i Monascus, među kojima ga najviše sintetizira $P$. citrinum. S obzirom na nedostatnost podataka o razinama citrinina u žitaricama, u okviru ovog istraživanja analizirane se njegove koncentracije u kukuruzu ( $n=158) \mathrm{s}$ obiteljskih poljoprivrednih gospodarstava u Hrvatskoj tijekom petogodišnjeg razdoblja (2017.-2021.). Tijekom petogodišnjeg razdoblja citrinin je detektiran u 25,3 \% uzoraka kukuruza prikupljenih na području cijele

Hrvatske. Najveća prosječna koncentracija utvrđena je 2016. godine $(162,9 \pm 162,0 \mu \mathrm{g} /$ $\mathrm{kg})$ te 2020. godine $(154,9 \pm 358,8 \mu \mathrm{g} / \mathrm{kg})$, a najveća koncentracija od 968,6 $\mu \mathrm{g} / \mathrm{kg}$ određena je u 2020. godini u uzorku kukuruza uzorkovanom na području južne regije Hrvatske. S obzirom na utvrđenu značajniju kontaminaciju pojedinih uzoraka, može se zaključiti o nužnosti sustavnog nadzora citrinina u hrani za ljude i u hrani za životinje, kao i definiranju najvećih dopuštenih količina ovog mikotoksina u okviru zakonodavstva.

Ključne riječi: citrinin, kontaminacija žitarica, kukuruz, najveća dopuštena količina, zakonodaustvo

\section{Uvod}

Mikotoksini su tvari koje predstavljaju sekundarne metabolite plijesni, a učestalo kontaminiraju hranu ljudi i hranu za životinje u ovisnosti o klimatskim i broj-

nim drugim čimbenicima utjecaja (Pleadin i sur., 2020.). Citrinin je mikotoksin kojeg sintetizira nekoliko vrsta plijesni iz rodova Penicillium, Aspergillus i Monas-

Dr. sc. Jelka PLEADIN, dipl. ing. biotehnol., znanstvena savjetnica u trajnom zvanju, redovita profesorica, dr. sc. Nina KUDUMIJA, dipl. ing. preh. tehnol., stručna savjetnica; Tina LEŠIĆ, mag. ing. biotehnol., viša stručna suradnica, Lidija DERGESTIN BAČUN, dipl. ing. preh. tehnol., viša stručna suradnica, Hrvatski veterinarski institut, Zagreb, Hrvatska; dr. sc. Jadranka FRECE, dipl. ing. biotehnol., redovita profesorica, dr. sc. Ivana KMETIČ, dipl. ing. biotehnol., izvanredna profesorica, dr. sc. Ksenija MARKOV*, dipl. ing. biotehnol., redovita profesorica, (dopisni autor, e-mail: kmarko@pbf.hr), Prehrambeno-biotehnološki fakultet, Zagreb, Hrvatska 
cus. Najviše ga sintetizira $P$. citrinum koja je široko rasprostranjena plijesan i može se izolirati iz bilo koje pljesnive hrane za ljude i hrane za životinje (Bennett i Klich, 2003., Houbraken i sur., 2011., Doughari, 2015.). $P$. citrinum raste na temperaturi od $5-40{ }^{\circ} \mathrm{C}$, s optimalnim rastom na $26-30{ }^{\circ} \mathrm{C}$ $\mathrm{i}$ aktivitetom vode $\left(\mathrm{a}_{\mathrm{w}}\right)$ manjim od 0,80 (Pitt i Hocking, 2009.); osjetljiv je na toplinu i tijekom toplinske obrade se razlaže (Ostry i sur., 2013.).

Toksičnost citrinina u ljudi i životinja još uvijek nije detaljno ispitana (EFSA, 2012.). No poznato je da je kao i okratoksin A nefrotoksičan te se pretpostavlja da je uključen u razvoj balkanske endemske nefropatije (BEN) koju karakteriziraju bubrežna tubularna degeneracija, intersticijska fibroza, anemija, gubitak težine i poliurija. Osim nefrotoksičnosti, istraživanja su ukazala i na potencijalne hepatotoksične, teratogene, fetotoksične i genotoksične učinke citrinina (Liu i sur., 2003., Amalaradjou i Venkitanarayanan, 2008., Flajs i Peraica, 2009. Qingqing i sur., 2010.). Utvrđeno je i da citrinin povećava toksičnost okratoksina A, kako aditivno tako i sinergistički (Ji i sur., 2015.). Zbog nedostatka relevantnih istraživanja o njegovoj kancerogenosti, Međunarodna agencija za istraživanje raka (IARC) svrstala je citrinin u treću skupinu karcinogenih spojeva (IARC, 1986.), što upućuje na nužnost provedbe daljnjih toksikoloških studija.

Pojavnost citrinina dokazana je $\mathrm{u}$ različitim žitaricama i proizvodima na bazi žitarica, ali i u grahu, voću, sokovima od voća i povrća, bilju i začinima, maslinama i pljesnivom siru te nekim drugim namirnicama, podrijetlom iz različitih zemalja svijeta ( $\mathrm{Xu}$ i sur., 2006., EFSA, 2012., Markov i sur., 2013., Ji i sur., 2015., Pleadin i sur., 2018., Oztas i sur., 2020.). Ujedno, literaturni podatci ukazuju na moguću supojavnost okratoksina A i citrinina u hrani za ljude i za životinje (Vrabcheva i sur., 2000., Speijers i Speijers, 2004., Pleadin i sur.,
2015., Pleadin i sur., 2018.). Pleadin i sur. (2018.) su u ranijem istraživanju u Hrvatskoj odredili značajne razine u pojedinim uzorcima neprocesiranih žitarica te oko 15 puta veće koncentracije citrinina $\mathrm{u}$ odnosu na koncentracije okratoksina A.

Panel Europske agencije za sigurnost hrane (EFSA, engl. European Food Safety Authority) o kontaminatima u prehrambenom lancu (CONTAM, engl. The EFSA Panel on Contaminants in the Food Chain) je 2012. godine zaključio o mogućem riziku za zdravlje ljudi i životinja povezan s prisutnošću citrinina u hrani za ljude i za životinje (EFSA, 2012.). Utvrđena je nužnost prikupljanja daljnih podataka o pojavnosti citrinina u hrani u Europi da bi se mogla provesti utemeljena procjena rizika. Stoga je 2015. godine od strane EFSA objavljen poziv za podnošenje prijedloga o istraživanjima citrinina $\mathrm{u}$ žitaricama i proizvodima na bazi žitarica iz različitih zemljopisnih regija u Europi. Važno je istaknuti da u Europskoj uniji još uvijek nije propisana najveća dopuštena (NDK) ili najveća preporučena količina citrinina u hrani za ljude i za životinje.

Slijedom potrebe za daljnjim praćenjem pojavnosti citrinina, cilj ovog istraživanja bio je ispitati njegovu pojavnost $\mathrm{u}$ kukuruzu s obiteljskih gospodarstava u Hrvatskoj tijekom petogodišnjeg razdoblja te usporediti dobivene vrijednosti s ranije dobivenim podatcima o količinama citrinina u ovoj i ostalim vrstama žitarica podrijetlom iz Hrvatske, kao i drugih europskih zemalja.

\section{Materijali i metode}

\section{Uzorkovanje i priprema uzoraka}

Uzorci kukuruza uzorkovani su s obiteljskih poljoprivrednih gospodarstava iz pet regija Hrvatske tijekom razdoblja 2017.-2021. godine. Uzorkovanjem po regijama Hrvatske obuhvaćene su sljedeće županije: sjeverna 
regija (Međimurska, Varaždinska, Koprivničko-križevačka i Krapinskozagorska), središnja regija (Zagrebačka, Sisačko-moslavačka, Karlovačka i Bjelovarsko-bilogorska), zapadna regija (Istarska i Primorsko-goranska), istočna regija (Virovitičko-podravska, Požeškoslavonska, Osječka, Brodsko-posavska i Vukovarsko-srijemska) i južna regija (Zadarska, Splitsko-dalmatinska i Dubrovačko-neretvanska). Kukuruz je u domaćinstvima bio uskladišten u vrećama, uglavnom na tavanskim i podrumskim prostorijama. Uzorkovanje je provedeno 4-6 mjeseci nakon pohrane uzoraka (razdoblje od veljače do travnja tijekom svake kalendarske godine), a svaki uzorak uzet je u količini od 1,5-2 kg.

Uzorci kukuruza su nakon uzorkovanja unutar 48 sati transportirani u laboratorij. Po 500 g svakog uzorka pomoću analitičkog mlina Cylotec 1093 (Tecator, Švedska) samljeveno je u fini prah veličine čestica od $1,0 \mathrm{~mm}$ te su pohranjeni na $4{ }^{\circ} \mathrm{C}$ do provedbe analiza.

\section{Kemikalije i uređaji}

Ridascreen FAST Citrinin ELISA kit (art. Br. R6302), korišten za provedbu ELISAmetoda, nabavljenjeodR-Biopharm (Darmstadt, Njemačka). Pakiranje sadrži mikrotitracijsku ploču sa 48 jažica, pet standardnih otopina citrinina $(0,15,45$, 135 i $405 \mu \mathrm{g} / \mathrm{L})$, konjugat (peroksidom), antitijelo, otopinu supstrata/kromogena (tetrametilbenzidin) i stop otopinu (1N sumporna kiselina). Sve ostale kemiklije korištene za pripremu uzoraka bile su analitičke čistoće. ELISA test proveden je pomoću automatiziranog analizatora ChemWell 2910 (Awareness Technology Inc., SAD).

\section{Ekstrakcija i određivanje citrinina}

U $5 \mathrm{~g}$ homogeniziranog uzorka kukuruza dodano je 12,5 mL 70\%-tnog metanola. Ekstrakcija je postignuta snažnim mućkanjem na tresilici tijekom 3 min, nakon čega su ekstrakti filtrirani kroz filter papir (crna vrpca, Whatman). Filtrat je razrijeđen deioniziranom vodom $(1+1)$ te je $50 \mu \mathrm{L}$ otopine upotrijebljeno za ELISA test. Kompetitivna ELISA metoda provedena je potpuno u skladu s uputama proizvođača kita. Nakon dodavanja stop otopine, izmjerene su apsorbancije pri $450 \mathrm{~nm}$. Kako bi se odredila koncentracija $(\mu \mathrm{g} / \mathrm{kg})$ citrinina u svakom uzorku, rezultati dobiveni na kalibracijskoj krivulji pomnoženi su s odgovarajućim faktorom razrjeđivanja uzorka. Primjenjena validirana ELISA metoda ima vrijednost limita detekcije (LOD) od 15,0 $\mu \mathrm{g} / \mathrm{kg}$. Ranije provedeni validacijski postupci korištene metode rezultirali su s iskorištenjem od 81,3\% i koeficijentom varijacije (CV) od 9,4\% (Pleadin i sur., 2018.).

Tabela 1. Količina citrinina u kukuruzu s područja Hrvatske po godinama uzorkovanja

\begin{tabular}{|c|c|c|c|c|c|c|}
\hline Godina & $\begin{array}{c}\text { Broj } \\
\text { uzoraka }\end{array}$ & $\begin{array}{c}\text { \% } \\
\text { pozitivnih }\end{array}$ & $\begin{array}{c}\text { Srednja } \\
\text { vrijednosta } \\
(\mu \mathrm{\mu g} / \mathrm{kg})\end{array}$ & $\begin{array}{c}\text { SD } \\
(\mu \mathrm{gg} / \mathrm{kg})\end{array}$ & $\begin{array}{c}\text { Min } \\
(\mu \mathrm{g} / \mathrm{kg})\end{array}$ & $\begin{array}{c}\text { Max } \\
(\mu \mathrm{\mu g} / \mathrm{kg})\end{array}$ \\
\hline 2017. & 22 & 18,2 & 162,9 & 162,0 & 70,6 & 405,0 \\
\hline 2018. & 32 & 18,8 & 21,5 & 9,3 & 16,0 & 39,8 \\
\hline 2019. & 38 & 26,3 & 26,1 & 15,0 & 16,8 & 66,3 \\
\hline 2020. & 30 & 43,3 & 27,4 & 10,6 & 15,8 & 56,1 \\
\hline 2021. & 36 & 19,4 & 154,9 & 358,8 & 16,4 & 968,6 \\
\hline Ukupno & 158 & 25,3 & 62,1 & 159,7 & 15,8 & 968,6 \\
\hline
\end{tabular}

a Srednja se vrijednost odnosi na uzorke u kojima je citrinin detektiran $(>15 \mu \mathrm{g} / \mathrm{kg})$ 
Tabela 2. Količina citrinina u kukuruzu određena tijekom petogodišnjeg razdoblja (2017.-2021.) po regijama Hrvatske

\begin{tabular}{|c|c|c|c|c|c|c|c|}
\hline Regija RH & $\begin{array}{c}\text { Broj } \\
\text { uzoraka }\end{array}$ & $\begin{array}{c}\text { \% ukupno } \\
\text { pozitivnih }\end{array}$ & $\begin{array}{c}\% \\
\text { pozitivnih } \\
\text { po regiji }\end{array}$ & $\begin{array}{c}\text { Srednja } \\
\text { vrijednost } \\
(\mu \mathrm{\mu g} / \mathrm{kg})\end{array}$ & $\begin{array}{c}\mathrm{SD} \\
(\mu \mathrm{g} / \mathrm{kg})\end{array}$ & $\begin{array}{c}\text { Min } \\
(\mu \mathrm{\mu g} / \mathrm{kg})\end{array}$ & $\begin{array}{c}\text { Max } \\
(\mu \mathrm{\mu g} / \mathrm{kg})\end{array}$ \\
\hline Sjeverna & 56 & 12,0 & 33,9 & 26,7 & 20,6 & 15,8 & 102,0 \\
\hline Središnja & 25 & 2,5 & 16,0 & 128,9 & 186,0 & 16,0 & 405,0 \\
\hline Zapadna & 7 & 0,0 & 0,0 & $<$ LOD & $<$ LOD & $<$ LOD & $<$ LOD \\
\hline Istočna & 43 & 5,7 & 20,9 & 28,0 & 16,6 & 16,0 & 70,6 \\
\hline Južna & 27 & 5,1 & 29,6 & 151,0 & 330,7 & 18,0 & 968,6 \\
\hline
\end{tabular}

$<$ LOD - manje od limita detekcije analitičke metode (LOD = $15 \mu \mathrm{g} / \mathrm{kg}$ )

Srednja se vrijednost odnosi na uzorke u kojima je citrinin detektiran (> 15 $\mu \mathrm{g} / \mathrm{kg})$

\section{Rezultati i rasprava}

Rezultati pojavnosti citrinina $u$ kukuruzu određeni u okviru ovog istraživanja u svim regijama Hrvatske, po godinama uzorkovanja tijekom petogodišnjeg razdoblja (2017.-2021.), prikazani su u Tabeli 1.

Tijekom petogodišnjeg razdoblja uzorkovanja citrinin je detektiran $u$
25,3 \% uzoraka kukuruza prikupljenih na obiteljskim gospodarstvima na području cijele Hrvatske. Najveća prosječna koncentracija utvrđena je 2016. godine $(162,9 \pm 162,0 \mu \mathrm{g} / \mathrm{kg})$ te 2020 . godine $(154,9 \pm 358,8 \mu \mathrm{g} / \mathrm{kg})$, a najveća koncentracija od $968,6 \mu \mathrm{g} / \mathrm{kg}$ određena je u 2020. godini. S obzirom na dobivene visoke vrijednosti standardnih devijacija, naročito za 2017. i 2021. godinu, može se
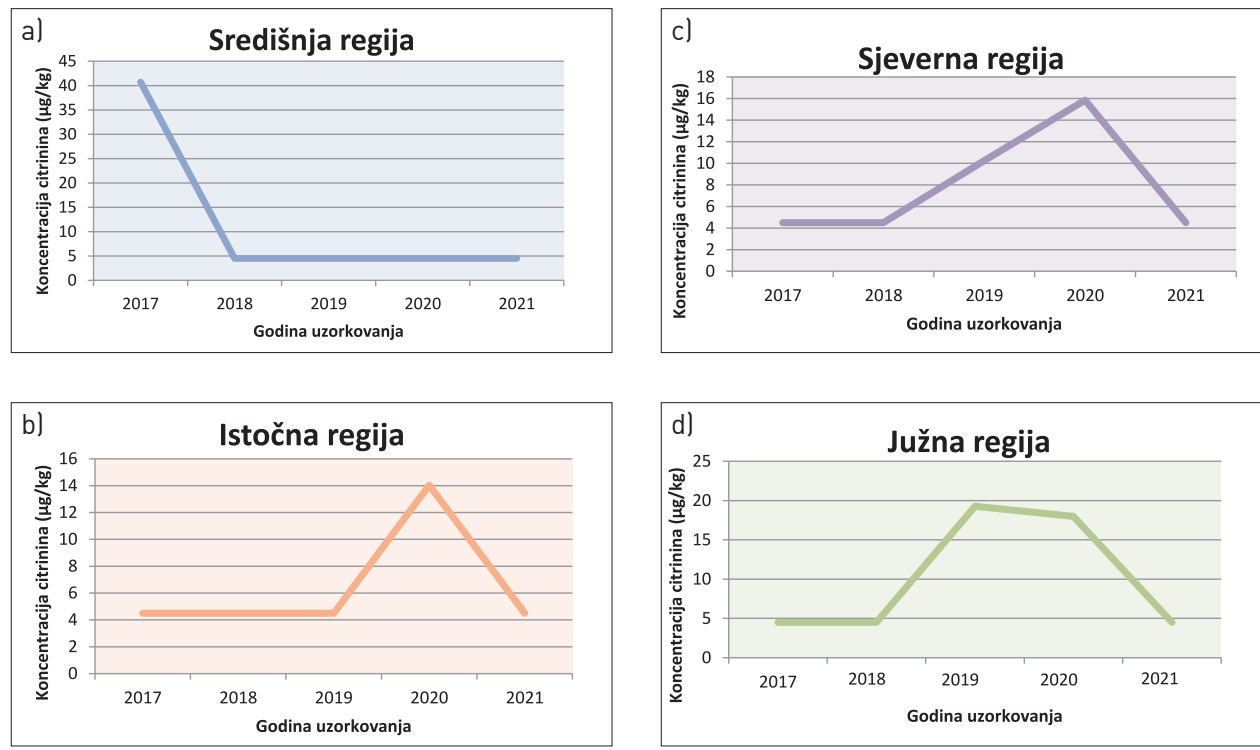

Slika 1. Medijan koncentracija citrinina po regijama Hrvatske i godinama uzorkovanja tijekom petogodišnjeg razdoblja: a) središnja regija; b) istočna regija; c) sjeverna regija; d) južna regija *Za uzorke u kojima citrinin nije detektiran za izračun i prikaz rezultata uzeta je vrijednosti 0,5 LOD $(7,5 \mu \mathrm{g} / \mathrm{kg})$ 
zaključiti o širokom variranju utvrđenih koncentracija citrinina u kukuruzu, odnosno o njegovoj sporadičnoj pojavnosti u pojedinim uzorcima.

U tabeli 2. prikazane su količine citrinina $\mathrm{u}$ kukuruzu po regijama Hrvatske, sumarno za sve godine uzorkovanja. Rezultati medijana svih koncentracija citrinina za svaku regiju zasebno, po godinama uzorkovanja, prikazani su na slici 1. (a.-d). U zapadnoj regiji citrinin nije detektiran te stoga grafički podatci nisu prikazani.

Najveći udio pozitivnih uzoraka određen je u središnjoj Hrvatskoj (33,9\% u regiji i $12,0 \%$ u odnosu na ukupan broj uzoraka). Unatoč niskoj razini pojavnosti citrinina u uzorcima iz južne Hrvatske $(5,1 \%$ u odnosu na ukupan broj uzoraka), najveća razina kontaminacije $(968,6 \mu \mathrm{g} / \mathrm{kg})$ određena je u jednom uzorku kukuruza nepoznatog podrijetla. Nadalje, u jednom uzorku iz središnje regije određena je koncentracija citrinina od $405,0 \mu \mathrm{g} / \mathrm{kg}$, sa $16 \%$ pozitivnih uzoraka iz te regije. $S$ područja zapadne Hrvatske citrinin nije detektiran niti u jednom uzorku.

U južnoj i sjevernoj regiji najveći postotak pozitivnih uzoraka određen je 2019. i 2020. godine, s medijanima od $19,27 \mu \mathrm{g} / \mathrm{kg}$ i $17,99 \mu \mathrm{g} / \mathrm{kg}$ u južnoj regiji, odnosno, $10,26 \mu \mathrm{g} / \mathrm{kg}$ i $15,85 \mu \mathrm{g} / \mathrm{kg}$ u sjevernoj regiji. U središnjoj regiji najveći postotak pozitivnih uzoraka određen je 2017. godine s medijanom od $40,71 \mu \mathrm{g} /$ $\mathrm{kg}$, dok u istočnoj regiji 2020. godine $\mathrm{s}$ medijanom od $14,04 \mu \mathrm{g} / \mathrm{kg}$. Rezultati ukazuju na široko variranje utvrđenih koncentracija citrinina u kukuruzu, odnosno na njegovu sporadičnu pojavnost $\mathrm{u}$ pojedinim uzorcima, što se može vjerojatno dovesti $u$ vezu $s$ klimatskim i ostalim agrotehničkim uvjetima tijekom uzgoja kukuruza, odnosno s neprikladnim uvjetima pohrane ove žitarice tijekom razdoblja čuvanja.
Budući da najveće dopuštene ili preporučene količine citrinina za hranu za ljude i za životinje još uvijek nisu zakonodavstvom propisane, količine dobivene $\mathrm{u}$ ovom istraživanju ne mogu se uspoređivati $\mathrm{s}$ propisanim te ih uspoređujemo s rezultatima iz ostalih europskih zemalja i rezultatima iz naših ranijih istraživanja. Podatci EFSA iz 2012. godine, koji su uključivali 30 uzoraka žitarica i proizvoda na bazi žitarica, pokazali su da u 23 uzorka citrinin nije detektiran, a u tri uzorka koncentracija citrinina je bila manja od limita detekcije primjenjene analitičke metode (EFSA, 2012.). U četiri uzorka određen je citrinin u koncentracijama od 1,8; 5,2; 13,2 i $13,6 \mu \mathrm{g} / \mathrm{kg}$. Budući da dobiveni podatci nisu dostatni za utemeljenu procjenu CONTAM je zaključio da se iz dobivenih rezultata ne može provesti procjena unosa citrinina u ljudski organizam.

$\mathrm{Na}$ području Europe koncentracije citrinina u žitaricama široko su varirale, a pojedina istraživanja ukazala su i na značajnije razine onečišćenja. Kononenkoi Burkin (2008.) su analizom žitarica ( $n=766$ ) detektirali citrinin u 4,5\% analiziranih uzoraka pšenice te 3,6 \% uzoraka ječma, dok je najmanji udio $(1,9 \%)$ pozitivnih uzoraka određen za kukuruz. Međutim, utvrđene koncentracije u kukuruzu imale su značajne vrijednosti i kretale su se u rasponu od 218 do $953 \mu \mathrm{g} / \mathrm{kg}$. Curtui i sur. (1998.) su u 55 uzoraka pšenice i kukuruza $\mathrm{u}$ Rumunjskoj detektirali citrinin u jednom uzorku kukuruza u koncentraciji od $580 \mu \mathrm{g} / \mathrm{kg}$. Svi analizirani uzorci sadržavali su citrinin u koncentracijama od 17 do $405 \mu \mathrm{g} / \mathrm{kg}$, dok je u $25 \%$ uzoraka njegova koncentracija bila veća od $405 \mu \mathrm{g} / \mathrm{kg}$. U Bugarskoj su u uzorcima hrane za svinje i piliće, uzorkovanim na farmi na kojoj su prilikom klanja uočeni pokazatelji nefropatije (povećani i blijedo i šarani izgled bubrega), određene povećane količine citrinina. U 2006. godini ovaj mikotoksin je detektiran u $92 \%$ uzoraka hrane za životinje s 
prosječnom koncentracijom od $54,7 \pm 27,5$ $\mu \mathrm{g} / \mathrm{kg}$ te u 2007. godini u $96 \%$ uzoraka i koncentracijom od $120,5 \pm 43,3 \mu \mathrm{g} / \mathrm{kg}$ (Stoev i sur., 2010.). Utvrđene razine iz spomenutih istraživanja ukazuju na moguću značajnu kontaminaciju različitih žitarica citrininom, ujedno i kukuruza, koji općenito predstavlja vrlo značajnu žitaricu za prehranu ljudi i hranidbu životinja u Hrvatskoj.

EFSA je 2017. godine objavila podatke europskih istraživanja iz 2015. i 2016. godine (López Sánchez i sur., 2017.), pri čemu je analizirano ukupno 1195 industrijskih žitarica (pšenica, ječam, raž, zob i riža) i uzoraka gotovih proizvoda iz osam zemalja EU (Francuska, Njemačka, Italija, Litva, Nizozemska, Poljska, Španjolska i Švedska). Citrinin je kvantificiran u $6 \%$ industrijskih žitarica i $3 \%$ proizvoda na bazi žitarica. Općenito, razine citrinina u gotovim proizvodima bile su niže od onih u žitaricama, a najveća koncentracija citrinina određena $\mathrm{u}$ industrijskim žitaricama iznosila je 155 $\mu \mathrm{g} / \mathrm{kg}$ te $\mathrm{u}$ uzorcima na bazi žitarica iz maloprodaje 5,7 $\mu \mathrm{g} / \mathrm{kg}$. Međutim, u ovom istraživanju razine citrinina $\mathrm{u}$ kukuruzu nisu ispitivane.

U istraživanju Pleadin i sur. (2018.) provedenom tijekom 2014.-2016. na žitaricama u Hrvatskoj citrinin je određen u $49 \%$ uzoraka različitih žitarica, pri čemu je srednja koncentracija tijekom istraživanog trogodišnjeg razdoblja iznosila $66,8 \pm 76,0 \mu \mathrm{g} / \mathrm{kg}$. Najveća prosječna količina utvrđena je u pšenici $(124 \pm 24 \mu \mathrm{g} / \mathrm{kg})$ tijekom 2015. godine, s najvećom vrijednošću od $374 \mu \mathrm{g} / \mathrm{kg}$, a u kukuruzu je najveća prosječna koncentracija $(71,4 \pm 58,7 \mu \mathrm{g} /$ $\mathrm{kg}$ ) određena 2016. godine, s najvećom vrijednošću od $247 \mu \mathrm{g} / \mathrm{kg}$. U pozitivnim uzorcima utvrđene su značajno manje koncentracije mikotoksina u kukuruzu i ječmu iz 2014. u odnosu na uzorke iz 2015. i 2016. godine. U usporedbi s rezultatima dobivenim za žitarice uzorkovane iz osam europskih zemalja $u$ razdoblju od rujna 2015. do studenog 2016., koji su rezultirali sa $6 \%$ pozitivnih uzoraka i koncentracijom citrinina $\mathrm{u}$ rasponu od 1,1 do $155 \mu \mathrm{g} / \mathrm{kg}$ (López Sánchez i sur., 2017.), razina kontaminacije uočena u kukuruzu iz ovog istraživanja može se smatrati značajno većom i usporedivom s rezultatima pojedinih europskih istraživanja provedenih tijekom ranijeg razdoblja također na kukuruzu.

\section{Zaključak}

Pojavnost citrinina dokazana je u ukupno 25,3 \% uzoraka kukuruza prikupljenih tijekom petogodišnjeg razdoblja na obiteljskim gospodarstvima s područja cijele Hrvatske. Njegova najveća prosječna koncentracija utvrđena je 2017. i 2021. godine, a najveća pojedinačna vrijednost određena je u 2021. godini $u$ jednom uzorku kukuruza uzorkovanom na području južne regije. Rezultati ukazuju na široko variranje utvrđenih koncentracija citrinina u kukuruzu, odnosno na njegovu sporadičnu pojavnost $\mathrm{s}$ visokim koncentracijama $\mathrm{u}$ pojedinim uzorcima, što se može dovesti u vezu s klimatskim i ostalim uvjetima tijekom uzgoja kukuruza, odnosno neprikladnim uvjetima njegove pohrane. Stoga su potrebna daljnja istraživanja pojavnosti citrinina $\mathrm{u}$ jasnoj poveznici s uvjetima uzgoja i pohrane žitarica te provedba sustavnog nadzora i što skorije definiranje najvećih dopuštenih količina ovog kontaminanta za hranu za ljude i za životinje.

\section{Literatura}

1. AMALARADJOU, M. A. R. and K. VENKITANARAYANAN (2008): Detection of Penicillium, Aspergillus and Alternaria species in fruits and vegetables. In: Barkai-Golan, R., N. Paster: Mycotoxins in Fruits and Vegetables. Academic Press, Elsevier (225-249).

2. BENNETT, J. W. and M. KLICH (2003): Mycotoxins. Clin. Microbiol. Rev. 3, 497-516.

3. CURTUI, V., E. USLEBER, R. DIETRICH, J. LEPSCHY and E. MÄRTLBAUER (1998): A survey 
on the occurrence of mycotoxins in wheat and maize from western Romania. Mycopathologia 143, 97-103.

4. DOUGHARI, J. H. (2015): The occurrence, properties and significance of citrinin mycotoxin. J. Plant. Pathol. Microbiol. 6, 1-6.

5. EUROPEAN FOOD SAFETY AUTHORITY (EFSA) (2012): Scientific opinion on the risks for public and animal health related to the presence of citrinin in food and feed. EFSA Panel on Contaminants in the Food Chain (CONTAM). EFSA J. 10, 1-81.

6. FLAJS, D. and M. PERAICA (2009): Toxicological properties of citrinin. Arh. Hig. Rada Toksikol. 60, 457-464.

7. HOUBRAKEN, J., J. C. FRISVAD and R. A. SAMSON (2011): Taxonomy of Penicillium section Citrina. Stud. Mycol. 70, 53-138.

8. INTERNATIONAL AGENCY FOR RESEARCHON CANCER (IARC) (1986): Citrinin. Some Naturally Occurring and Synthetic Food Components, Furocoumarins and Ultraviolet Radiation. IARC Monographs on the Evaluation of Carcinogenic Risks to Humans. 40, 67.

9. JI, X., J. XU, X. WANG, P. QI, W. WEI, X. CHEN, R. LI and Y. ZHOU (2015): Citrinin determination in red fermented rice products by optimized extraction method coupled to liquid chromatography tandem mass spectrometry (LC-MS/MS). J. Food Sci. 80, 1438-1444.

10. KONONENKO, G. P. and A. A. BURKIN (2008): A survey on the occurrence of citrinin in feeds and their ingredients in Russia. Mycotox Res. 24, 3-6.

11. LIU, B. H., F. Y. YU, T. S. WU, A. Y. LI, M. C. SU, M. C. WANG and S. M. SHIH (2003): Evaluation of genotoxic risk and oxidative DNA damage in mammalian cells exposed to mycotoxins, patulin and citrinin. Toxicol. App. Pharmacol. 191, 255-263.

12. LÓPEZ, P., M. DE NIJS, M. SPANJER, A. PIETRI, T. BERTUZZI, A. STARSKI, J. POSTUPOLSKI, M. CASTELLARI and M. HORTÓS (2017): Generation of occurrence data on citrinin in food. EFSA supporting publication 2017, EN-1177, 47.

13. MARKOV, K., J. PLEADIN, M. BEVARDI, N. VAHČIĆ, D. SOKOLIĆ-MIHALAK and J. FRECE (2013): Natural occurence of aflatoxin $B_{1}$, ochratoxin $A$ and citrinin in Croatian fermented meat products. Food Cont. 34, 312-317.
14. OSTRY, V., F. MALIR and J. RUPRICH (2013): Producers and important dietary sources of ochratoxin A and citrinin. Toxins 5, 1574-1586.

15. OZTAS, E., H. OZDEN and G. OZHAN (2020): A preliminary survey of citrinin contamination in dried fruits, molasses and liquorice products in Turkey. J. Food Nutr. Res. 59, 81-86.

16. PITT, J. I. and A. D. HOCKING (2009): Fungi and food spoilage. Springer, New York.

17. PLEADIN, J., M. ZADRAVEC, T. LEŠIĆ, J. FRECE, V. VASILJ and K. MARKOV (2020): Climate change - A potential threat for increasing occurrences of mycotoxins. Vet. Stn. 51, 659-671. (In Croatian).

18. PLEADIN, J., M. ZADRAVEC, T. LEŠIĆ, N. VAHČIĆ, J. FRECE, M. MITAK and K. MARKOV (2018): Co-occurrence of ochratoxin A and citrinin in unprocessed cereals established during a threeyear investigation period. Food Addit. Contam. Part B 11, 20-25.

19. PLEADIN, J., N. KUDUMIJA, J. FRECE, D. PETROVIĆ and K. MARKOV (2015): Citrinin u hrani i hrani za životinje. Croatian J. Food Technol. Biotechnol. Nutr. 11, 84-90.

20. QINGQING, H., Y. LINBO, G. YUNQIAN and L. SHUQIANG (2010): Toxic effects of citrinin on the male reproductive system in mice. Exp. Toxicol. Pathol. 64, 465-469.

21. SPEIJERS, G. J. A. and M. H. M. SPEIJERS (2004): Combined toxic effects of mycotoxins. Toxicol. Lett. 153, 91-98.

22. STOEV, S. D., M. F. DUTTON, P. B. NJOBEH, J. S. MOSONIK and P. A. STEENKAMP (2010): Mycotoxic nephropathy in Bulgarian pigs and chickens: complex aetiology and similarity to Balkan endemic nephropathy. Food Addit. Contam. Part A 27, 72-88.

23. VRABCHEVA, T., E. USLEBER, R. DIETRICH and E. MÄRTLBAUER (2000): Co-occurrence of ochratoxin A and citrinin in cereals from Bulgarian villages with a history of Balkan endemic nepropathy. J. Agric. Food Chem. 48, 2483-2488.

24. XU, B. J., X. Q. JIA, L. J. GU and C. K. SUNG (2006): Review on the qualitative and quantitative analysis of the mycotoxin citrinin. Food Cont. 17, 271-285. 


\section{Finding of citrinin in maize from Croatian family farms over a five-year period}

Jelka PLEADIN, BSc Biotehnol., PhD, Scientific advisor in tenure, Full Professor, Nina KUDUMIJA, BSc Food Tehnol., PhD, Expert Advisor, Tina LEŠIĆ, MSc Biotehnol., Senior Expert Associate, Lidija DERGESTIN BAČUN, BSc Food Tehnol., Senior Expert Associate, Croatian Veterinary Institute, Zagreb, Croatia; Jadranka FRECE, BSc Biotechnol., PhD, Full Professor, Ivana KMETIČ, BSc Biotechnol., PhD, Associate Professor, Ksenija MARKOV, BSc Biotechnol., PhD, Full Professor, Faculty of Food Technology and Biotechnology, Zagreb, Croatia

Mycotoxins frequently contaminate average concentrations were established food and animal feed, primarily cereals and in $2016(162.9 \pm 162.0 \mu \mathrm{g} / \mathrm{kg})$ and in 2020 cereal-based products. Citrinin is a mycotoxin $\quad(154.9 \pm 358.8 \mu \mathrm{g} / \mathrm{kg})$, and the maximum synthesized by several moulds from the concentration of $968.6 \mu \mathrm{g} / \mathrm{kg}$ was determined genera Penicillium, Aspergillus and Monascus, in 2020 in maize sampled from the southern including $P$. citrinum as the most significant producer. Given the lack of data on the levels of citrinin in cereals, its concentration in maize $(n=158)$ from family farms in Croatia was analysed over a five-year period (20172021). Citrinin was detected in $25.3 \%$ of maize samples collected from throughout Croatia during the five-year period. The highest region. Given the established significant contamination of certain samples, it can be concluded that there is a need for systematic control of citrinin in food and feed, and to stipulate the maximum permitted limits of this mycotoxin in the legislation.

Key words: citrinin; contamination of cereals; maize; maximum limit; legislation 